\title{
The "Ruler Legend": Tsar Nicholas I and the Route of the St. Petersburg-Moscow Railway, 1842-1843
}

Perhaps the most famous anecdote of the many connected with the reign of Tsar Nicholas I concerns the way in which he supposedly determined the route of the St. Petersburg-Moscow Railway. When asked by his officials the route along which it should be built, the tsar, on the spur of the moment, it is claimed, took a ruler, laid it on a map, and arbitrarily and hastily drew an absolutely straight line between the two capitals. The all-powerful despot had spoken, and his decision was carried out by his servile courtiers, regardless of consequences.

On February 22, 1843, Nicholas I did indeed command that the St. Petersburg-Moscow Railway be built in a straight line, bypassing the town of Novgorod; his decision, however, was reached as the result of prolonged, rational, and open discussion in government circles. I shall discuss the development of the "Ruler Legend," in what follows, but this study is devoted primarily to an examination of the way in which the tsar's decision was in fact made.

The Ruler Legend has always had more vitality on the popular than on the scholarly level, and it is not accepted by recent serious scholarship on pre-1861 Russian economic development. ${ }^{1}$ Although the legend as a full-blown anecdote cannot be traced back beyond $1864,{ }^{2}$ criticism of Nicholas I's decision regarding

1. For brief remarks on the subject, see Walter M. Pintner, Russian Economic Policy under Nicholas I (Ithaca, 1967), p. 150, n. 58; William L. Blackwell, The Beginnings of Russian Industrialization, 1800-1860 (Princeton, 1968), pp. 285 and 318; and J. N. Westwood, A History of Russian Railzeays (London, 1964), pp. 29-30.

2. An article in The Engineer stated: "Railway enterprise in Russia, in fact, may be said to have begun with Alexander II. His predecessor, it is true, started iron roads; but he did it more after the fashion of an ignorant soldier than as an enlightened disciple of George Stephenson. When Chevalier von Gerstner, the first promoter of railways in Russia, laid the plan of the line from St. Petersburg to Moscow before the Emperor Nicholas, his Majesty ... only vouchsafed a passing glance at the elaborate maps and designs which were outspread on the table before him. 'Is this the nearest road to Moscow?' he inquired; 'the quickest for transporting troops?' 'It is not,' replied the chevalier, 'the nearest road; but it is believed to be the best, as it connects all the great towns between the two capitals, and would, therefore, be of the utmost service in fostering trade and commerce.' 'But I want the shortest road,' interrupted Nicholas, 'so as to be able to go in a day from St. Petersburg to Moscow. Give me the map.' Which saying, the Emperor took up a roller [sic]—according to some accounts, the sword at his side-and with a pencil drew a straight line from St. Petersburg to Moscow. 'Here is my plan of the railway,' his Majesty exclaimed; 'let it be constructed accordingly.' And constructed it was after this very simple design, —of course, under extraordinary difficulties, and at a most enormous expense" (The Engineer [London], September 23, 1864, p. 193). This account was copied almost verbatim by a contemporary German journal (Zeitung des Vereins deutscher Eisenbahn-Verwaltungen, January 14, 1865, p. 20). It was passed on in this way to later historians of early Russian railways in that country (see Oskar Matthesius, "Russische Eisenbahnpolitik im neunzehnten Jahrhundert von 1836 bis 1881," Archiv für Eisenbahnzwesen, 26 [1903]: 972, n. 1). 
the straight route surfaced as early as the $1840 \mathrm{~s}^{3}$ and became widespread and open in the late 1850 s and the $1860 \mathrm{~s}$, when the question of building additional major railways was being debated. Among educated Russians the opinion became popular that railways should be built to connect all commercially important towns along their route, ${ }^{4}$ and it was claimed that bypassing Novgorod demonstrated how arbitrary and unenlightened Nicholas I was, since serious considerations of economic development were subordinated to his whims for speed in military transport and administrative convenience. Thus, he was supposed to have greatly increased initial costs of construction by building through hundreds of miles of swamps and to have damaged the commerce of once thriving towns like Novgorod, while the railway traversed nothing but barren, unpopulated wastes. These stories were duly picked up by foreign visitors, especially the British, who passed them on to the press of their native lands. ${ }^{5}$ The Ruler Legend gained far more acceptance outside of Russia, especially in the Anglo-American world, where it was regarded as a typical example of the manner in which Nicholas I, the stupid, brutal "Gendarme of Europe," carried on his domestic administration.

The meaning attached to the Ruler Legend underwent a curious metamorphosis starting in the late 1860s. The story itself persisted in Russia and abroad, but it began to be used increasingly to show Nicholas $I$ in a favorable light. It was said in Russia that his officials had wished the railway to diverge from a straight line in order to serve their personal or local interests. The tsar had taken his now famous ruler and ordered the railway built in a straight line to prevent this, a wise decision-it was claimed-since most passengers and freight were carried the whole length of the line. ${ }^{6}$ Thus, in the $1870 \mathrm{~s}$ and $1880 \mathrm{~s}$, most Russians writing on the history of early Russian railways stated that Nicholas I's decision was actually farsighted: over the years, both passengers and shippers had saved millions of rubles because of the shorter route, especially since the St. Petersburg-Moscow Railway was the most heavily traveled railroad route in the Russian Empire. His wisdom was contrasted with the self-interest of private railway companies in this later period, which, to reduce initial construction costs, would make their railways longer to avoid natural obstacles, thereby forcing passengers and shippers to pay higher rates after they were opened. ${ }^{7}$ Similarly, by the last decades of the nineteenth century, the legend was seen outside of Russia as a curious but illustrative anecdote showing Nicholas I as an all-powerful but farsighted autocrat, who, by merely giving an order, was able to put a sudden end

3. Great Britain, Public Record Office, Foreign Office Papers, Record Group 65, Diplomatic and consular reports from Russia to England, vol. 322, Andrew Buchanan to Viscount Palmerston, no. 45, September 26, 1846 (N.S.).

4. Molva, August 17, 1857, p. 218; D. I. Romanov, "Obshchaia set' russkikh zheleznykh dorog i vodianykh soobshchenii," Sovremennik, n.s., 113 (1866), sec. 1, pp. 42-43.

5. See, for example, Robert Harrison, Notes of a Nine Years' Residence in Russia, from 1844 to 1853 (London, 1855), p. 48; Charles H. Pearson, Russia, by a Recent Traveller (London, 1859), p. 16; cf. American Railroad Journal, November 6, 1858, p. 707.

6. J. F. Loubat, Narrative of the Mission to Russia in 1866 of the Hon. Gustarus Vasa Fox, Assistant-Secretary of the Navy (New York, 1873), p. 209; and Sir Donald Mackenzie Wallace, Russia, rev. ed. (New York, 1905), pp. 2-3.

7. A. A. Golovachev, "Zheleznye dorogi v Rossii," Sbornik gosudarstvennykh znanii, 4 (1877) : 232-33; P. E. Gronskii, "Ocherk vozniknoveniia i razvitiia zheleznykh dorog v Rossii," Zapiski moskovskogo otdeleniia Imperatorskogo russkogo tekhnicheskogo obshchestva, no. 4 (1886), p. 16. 
to the squabbling and self-interest of his advisers and mobilize all the resources of his realm to carry out his command. ${ }^{8}$

The original legend, however, has carried over on the popular level into the twentieth century. It is mentioned occasionally, usually with skepticism, in textbooks ${ }^{9}$ and popular works ${ }^{10}$ and shows amazing endurance in the AngloAmerican imagination. The vitality of this story typifies a widespread view of governmental decision making in Nicholas's Russia as impulsive and arbitrary. The story is wrong in fact and, even more significant, it is wrong in spirit. Highlevel decision making was not impulsive or arbitrary, but slow and ponderous, and yet thorough and rational as well. The choice of a route for the St. Petersburg-Moscow Railway provides a good illustration.

From the beginning, the basic issue concerning the route of the St. Petersburg-Moscow Railway was whether it should be built as straight as possible or follow a more circuitous route which would touch the most important towns between the two capitals, as did the Moscow Chaussée, the first major paved highway in Russia which was 450 miles long and completed in 1834 . It went from St. Petersburg to Moscow via Chudovo, Novgorod, Vyshnii Volochek, Tver', Torzhok, and Klin. The St. Petersburg-Moscow Railway, on the other hand, which was opened to the public in 1851, was built in a straight line, and was 403 miles long. It ran via Chudovo, Vyshnii Volochek, Tver', and Klin. For much of the distance between St. Petersburg and Moscow, the Chaussee, which even today is the main motor road between Leningrad and Moscow, and the railway roughly paralleled each other. Only between Chudovo near the Volkhov River and Vyshnii Volochek was there any great divergence. ${ }^{11}$ However, in this area lay the provincial capital Novgorod ("Lord Novgorod the Great"), which had played such a significant role in the history of Russia but which, by the nineteenth century, had declined considerably. Thus the question was whether Russia's first major railway should be built via Novgorod or follow a shorter; more direct route.

In 1842, Novgorod, with 16,700 inhabitants, was the largest town on the Moscow Chaussée, except for Tver'.12 As a provincial capital it was an administrative center as well as a garrison town, with many soldiers quartered in the city and its environs. ${ }^{13}$ But Novgorod and the surrounding area were poorly developed in respect to both manufacturing and agriculture. In 1842, Novgorod had twenty-seven manufacturing establishments, which employed a total of 177 workers. The largest ones produced bricks and candles. ${ }^{14}$ The climate of most of Novgorod province was as harsh as that of St. Petersburg, with a short growing

8. John Geddie, The Russian Empire (London, 1882), p. 28; and John L. W. Page, In Russia Without Russian (Plymouth, 1898), p. 81.

9. See, for example, Paul Dukes, A History of Russia (New York, 1974), p. 139.

10. For example, C. Hamilton Ellis, The Lore of the Train (New York, 1971), p. 76; cf. Albert Parry, Whistler's Father (Indianapolis, 1939), p. 75.

11. Severnaia pchela, April 27, 1839, p. 365; V. G. Voshchinin, Svedeniia o rossiiskikh zheleznykh dorogakh (St. Petersburg, 1862), pp. 5-6.

12. Tver' had a population of 17,000; St. Petersburg had 470,202 and Moscow 349,068 inhabitants (Zhurnal Ministerstva vnutrennikh del, 1 [1843] : 295).

13. Severnaia pcheia, August 10,1846, p. 710; Times (London), March 29, 1853, p. 6.

14. Severnaia pchela, August 19, 1847, p. 744, note*; P. Kriukov, Ocherk manufakturnopromyshlennykh sil evropeiskoi Rossii, vol. 2 (St. Petersburg, 1853), p. 135. 
season and poor soil conditions, causing agriculture to be confined mainly to the southern districts of the province. ${ }^{15}$

Although the Novgorod region was naturally poor, it did enjoy good water and road connections with St. Petersburg. The distance to St. Petersburg via the Volkhov River, the Ladoga Canal, and the Neva River was 246 miles, while Novgorod was 120 miles from St. Petersburg by the Moscow Chaussée. By far the greatest amount of Novgorod's commerce both by water and by the Chaussée was transit trade--particularly of grain from the richer areas to the southeastwhich made an important contribution to the economy of the town. Many inhabitants of the region, denied an adequate livelihood in agriculture, supported themselves by working as boat workers or carters. ${ }^{16} \mathrm{~A}$ factor in the economic wellbeing of Novgorod was supplying these workers with provisions for their further journey as well as providing eating and sleeping facilities for stagecoach and private carriage passengers and for carters passing through on the Chaussée. ${ }^{17}$

The building of a St. Petersburg-Moscow Railway would bring changes in the quantity and nature of this transit trade and travel through Novgorod, but, as the tsar later pointed out, these changes would be brought about more by the mere existence of a railway than by the fact that it bypassed Novgorod.

The arguments that were to recur until the final decision was made centered on the potential economic usefulness of the railway along one route or the other, on the comparative costs of construction and of operation and maintenance, and on the related cost to shippers and passengers. It should be noted that little consideration was given to the possibility that the railway, if built via Novgorod, would serve to develop the economy of that town. The emphasis was always on ascertaining how well the railway would serve existing economic needs and how much revenue could reasonably be expected. This emphasis on fairly certain costs and revenues and the disregard of any hypothetical development effects that the railway might bring to one locality seem only sensible in the face of a large and novel project such as a major railway in the Russia of the 1840 s, whether it was to be built by a private stock company or by a Russian government already strapped for funds.

Serious discussion of the route of the St. Petersburg-Moscow Railway began in government circles when, in March 1841, Nicholas I appointed a commission under Count $\mathrm{A}$. Kh. Benckendorff to study the railway project in detail. ${ }^{18}$ The Benckendorff commission recommended construction of the railway, ${ }^{19}$ and, on February 1, 1842, the tsar officially authorized construction-to be carried

15. "Sovremennoe polozhenie sel'skogo khoziaistva v Rossii," Sanktpeterburgskie vedomosti, July 11, 1847, p. 702; I. Kupriianov, "Mestnye ocherki Novgoroda," Moskvitianin, vol. 1, book 2 (January 1852), sec. 7, p. 57. p. 478.

16. Severnaia pchela, August 19, 1847, p. 744; Kommercheskaia gazeta, October 10, 1833,

17. Severnaia pchela, October 9, 1842, p. 903; Vestnik promyshlennosti, 1858, no. 3, sec. 3, p. 98.

18. In the years $1837-39$, proposals for a railway between the capitals had been submitted to the government in which there was at least brief discussion of its route. But the issue had never been decided, since the government rejected these proposals (see Richard Mowbray Haywood, The Beginnings of Railway Development in Russia in the Reign of Nicholas I, 1835-1842 [Durham, N.C., 1969], pp. 159-92).

19. For the full text of the Commission's report, see "Donesenie Nikolaiu I komissii po ustroistvu zheleznoi dorogi mezhdu Peterburgom i Moskvoi, 15 sentiabria 1841 g.," Krasnyi arkhiv, 76 (1936) : 127-44. 
out at the expense of the state. The commission had recommended building the railway in the most direct manner possible, bypassing Novgorod, since it was estimated that the largest amount of traffic would travel the entire route between capitals. The predicted amount of traffic from intermediate points, except Tver', was considered of secondary importance. The Moscow merchant, A. V. Abaza, who had been included in the Benckendorff commission at the specific request of the tsar, had made these same arguments earlier when, in March 1838, he submitted a proposal for a railway between the capitals. ${ }^{20}$ In this he represented the interests of the wealthier merchants of the two capitals, who were thinking primarily in terms of facilitating trade between Moscow, St. Petersburg, and foreign countries.

The recommendation for the straight route, however, by no means decided the route of the railway, for which additional, more detailed studies and surveys were considered necessary. On January 24, 1842, Nicholas assigned the responsibility for overall policy making-including a final determination of the routeand supervision of construction to a Construction Committee consisting mainly of members of the Committee of Ministers and high-ranking officers of the Corps of Transport Engineers. The Committee, under the chairmanship of his son and heir, Grand Duke Alexander Nikolaevich, was accountable to the tsar. A Construction Commission, including Lieutenant Colonel P. P. Mel'nikov and Colonel N. O. Kraft, both of whom had earlier been sent to study railways in America, was subordinated to the Committee, and charged with the immediate direction and supervision of construction, especially its technical aspects. ${ }^{21}$ It should be noted that most of the members of the original Benckendorff commission, all of whom were in favor of the direct route, served on one or both of these bodies.

From the very beginning, the Construction Committee was in favor of the direct route. At its first meeting on January 29 , it was stated that, because the preponderance of expected traffic would be between the two capitals, the railway should be made as short as possible. ${ }^{22}$ The next day, at its first meeting; the Construction Commission prepared to survey the route recommended by the Construction Committee and entrusted the task to Mel'nikov and Kraft. To determine whether this route was feasible from a purely technical standpoint, the Commission decided to make "reconnoitering surveys" between Chudovo and Vyshnii Volochek and between Vyshnii Volochek and Tver', since these stretches did not parallel the Moscow Chaussée and hence had been insufficiently surveyed. ${ }^{23}$

For the most part, the railway would traverse a relatively level terrain, although its route rose gradually from St. Petersburg and then more steeply beyond the Volkhov River over the Valdai Hills before descending toward Moscow, which was 434 feet higher than St. Petersburg. This allowed more favorable

20. Ibid., pp. 111-12.

21. For a list of the membership of the Construction Committee and the Construction Commission, see Haywood, The Beginnings of Railway Development, pp. 227-28.

22. N. A. Kislinskii, Nasha zheleznodorozhnaia politika po dokumentam arkhiva Komiteta ministrov, vol. 1 (St. Petersburg, 1902), pp. 26-27.

23. M. I. Voronin, "K istorii izyskanii i proektirovaniia Peterburgo-Moskovskoi zheleznoi dorogi," in Sbornik Leningradskogo Ordena Lenina Instituta inzhenerov zheleznodorozhnogo transporta, no. 143 (Moscow, 1952), p. 38. 
gradients in the direction of St. Petersburg, the direction in which most traffic was expected to go. ${ }^{24}$

Nonetheless, there were serious engineering problems. Despite the essentially level terrain over most of the railway's route, much of it was slightly undulating. This would require extensive earthworks, especially embankments, along much of the length of the railway, in order to keep the route as level and straight as possible (a particularly difficult problem in the Valdai Hills) and facilitate snow clearance in the winter. In a few places deep cuttings would be necessary. In addition, the rolling nature of the terrain produced basins which collected water from the winter snows (because the water could neither be absorbed by the clay soil nor entirely evaporate in the short summer). A floating vegetation accumulated in the water forming extensive morasses, or "swamps," generally one-three feet deep, but in some places fifteen-twenty feet deep. Moreover, it was necessary to bridge major rivers, such as the Volkhov, Msta, and Volga, and even some of their smaller tributaries, which had cut gorges over one hundred feet deep. ${ }^{25}$ The main problem was to avoid as many of these natural obstacles as possible while still keeping the railway essentially straight and level. At this time, before detailed surveys had been undertaken, it appeared that the terrain between Chudovo and Vyshnii Volochek might present especially serious engineering problems, a factor which was soon to give the advocates of the Novgorod route a chance to have their views taken into serious consideration.

In February, both Mel'nikov and Kraft, along with their assistants, were sent out to start the reconnoitering surveys. Their reports were examined by the Construction Commission on May 9, 1842, and by the Construction Committee on June 1. The routes surveyed-including some slight variations from the straight line to avoid natural obstacles-were sufficiently promising to be approved tentatively, and more detailed surveys were commissioned. ${ }^{26}$

Mel'nikov and Kraft were engaged in this project from June until December. Their additional surveys showed that the direct route between Chudovo and Vyshnii Volochek was feasible because the lakes and swamps either were not too deep or could be avoided by lengthening the railway by a few miles. Embankments and cuttings would not exceed practical limits, and enough timber for bridges and locomotive fuel would be available. The main problems were two very long and high bridges over the Msta and the Vereb'ia rivers and a steep gradient for about ten miles over the Valdai Hills in the direction of Moscow. ${ }^{27}$

Mel'nikov and Kraft's opinion was supported by the American engineer, Major George Washington Whistler, who, at their suggestion, had been invited by the Russian government to serve as a consulting engineer for the railway. $\mathrm{He}$ arrived in Russia in late July 1842 and, after inspecting the direct route, stated that the terrain was on the whole unusually favorable for the successful construction of the railway. ${ }^{28}$

24. See A. I. Shtukenberg, "Iz istorii zheleznodorozhnogo dela v Rossii," Russkaia starina, 48 (1885): 312-19.

25. New York Public Library, Manuscript Division, Patten Collection, Major George Washington Whistler to General Joseph G. Swift (St. Petersburg, January 18, 1847 [N.S.]).

26. N. S., "Materialy $\mathrm{k}$ istorii ustroistva S. Peterburgo-Moskovskoi (Nikolaevskoi) zheleznoi dorogi," Zhurnal Ministerstva putei soobshcheniia, 1, no. 1 (1886) : 296-98.

27. Ibid., p. 299; Voronin, " $\mathrm{K}$ istorii izyskanii i proektirovaniia," pp. 44-45.

28. N. S., "Materialy," p. 297. 
However, in spite of the predominant sentiment in favor of the direct route, the matter was as yet by no means settled. After January 1842, a minority of the Construction Committee-led by Count P. D. Kiselev, minister of state domains-continually and strongly urged that the possibility of building the railway via Novgorod be explored. According to a colleague, Kiselev, who was originally supported by Count V. V. Levashev and Count K. F. Toll, wanted the railway built via Novgorod because he felt that a major railway should always go through any towns of importance along its route. ${ }^{29}$ The governor of Novgorod, E. A. Zurov, also submitted a report stressing that this route would allow soldiers garrisoned in the Novgorod area to be transported easily to either capital. $^{30}$ Whatever the motivation of these supporters of the Novgorod route, the city's interests were advocated not by its local merchants-who lacked the numbers and influence in government circles that the merchants in the capitals had ${ }^{31}$ - but by a few high officials of the central government and by its chief representative in Novgorod.

In February 1842, Kiselev submitted two memorandums to the Construction Committee, urging the building of the railway via Novgorod. At a meeting on March 19, several members suggested that an alternate route between St. Petersburg and Vyshnii Volochek be surveyed, since, even if longer, it might present fewer engineering difficulties than the direct route and hence would be less costly to build; moreover, Novgorod would not be deprived of the advantages of the railway. The tsar was willing to have this route surveyed and entrusted the task to Mel'nikov. ${ }^{32}$

Mel'nikov started reconnoitering surveys on the Novgorod route. The route which he chose did not follow the Moscow Chaussée but went in a straight line from St. Petersburg to Novgorod. From Novgorod it roughly paralleled the Chaussée to Vyshnii Volochek. Thus, his surveys showed that, if the railway were built via Novgorod, the route would still be shorter than the Chaussee, because it did not follow the latter's circuitous route via Chudovo. ${ }^{33}$

In December 1842, Mel'nikov submitted reports containing the general plans and results of the surveys of both routes between St. Petersburg and Vyshnii Volochek, ${ }^{34}$ comparing them in respect to initial construction costs, yearly operation and maintenance costs, and transportation costs. It was these reports more than any other single factor that determined the decision by the majority of the Construction Committee and the tsar in favor of the direct route.

Mel'nikov estimated that the route of the railway between St. Petersburg and Vyshnii Volochek would be 223.5 miles via the direct route and 240 miles via

29. "Zapiski senatora K. I. Fishera," Istoricheskii vestnik, 112 (1908): 453.

30. B. Velikin, Peterburg-Moskva: Iz istorii Oktiabr'skoi zheleznoi dorogi (Leningrad, 1934), pp. 53-54. Another, earlier supporter of the Novgorod route was N. N. Murav'ev, a landowner in the Novgorod area and former governor of that province, who, in January 1839, had submitted a memorandum to the government proposing that the railway be built via Novgorod, since the environs of that city supplied St. Petersburg with much of its requirements for hay, which could then be shipped cheaply by railway (Tsentral'nyi gosudarstvennyi istoricheskii arkhiv SSSR, fond 1263, delo 1250 [g. 1839], pp. 389-93).

31. In 1842 the merchants of the first two "guilds," that is, the more substantial members of their class, in Novgorod numbered only 45 , while in St. Petersburg there were 337 and in Moscow 1625 (Zhurnal Ministerstva vnutrennikh del, pp. 296-97).

32. Kislinskii, Nasha zhelesnodorozhnaia politika, p. 27.

33. For details, see Voronin, "K istorii izyskanii i proektirovaniia," pp. 46-47.

34. N. S., "Materialy," pp. 299-300. 
Novgorod, a difference of 16.5 miles. But, because the latter route had not yet been surveyed in detail, it was likely that about 7 more miles would need to be added in order to avoid swamps or hills. Aside from any anticipated engineering difficulties, the additional length would add to construction costs for such items as iron rails, wooden crossties, ballast, and so forth. Some engineering problems involved no clear advantage for either route. In regard to swamps, Mel'nikov stated that their extent along the direct route was 16 miles greater but that many of the swamps along the Novgorod route were much deeper, so that the difficulties in this respect would be roughly equal. In regard to the serious question of gradients over the Valdai Hills, they would be approximately the same in respect to both length and incline.

The Novgorod route had the principal advantage of requiring fewer large bridges and shorter and lower ones over the Volkhov and Msta rivers. But its main disadvantage was that it would require earthworks-originally estimated by the Benckendorff commission as the largest single item of expense-that were 46 percent more extensive than those on the direct route, including some embankments 105 feet high and cuttings 95 feet deep, thereby raising construction costs.

Mel'nikov estimated, in summary, that for the part of the railway between St. Petersburg and Vyshnii Volochek initial construction costs would be 17.5 percent greater and annual operation and maintenance costs 10 percent greater if the railway were built via Novgorod. But he placed much more emphasis on the fact that lengthening the railway between the capitals by $20-23$ miles would mean 5 percent higher fares and freight rates for travelers and goods going the full distance-all for the benefit of Novgorod alone, a small city of relatively little commercial importance. Since the railway was intended primarily for traffic between St. Petersburg and Moscow, and was important for Russia as a whole, such additional expenses were to be avoided. If Novgorod needed a railway, a branch could be built from Chudovo later. ${ }^{35}$

The survey results and Mel'nikov's reports were submitted to the Technical Commission of the Department of Railways, which voted unanimously in favor of the direct route ${ }^{36}$ The Technical Commission estimated the cost of building the Novgorod route to be an additional 5,714,285 silver rubles (20 million paper rubles) and the annual cost of operation and maintenance to be 285,714 silver rubles ( 1 million paper rubles) more than the alternative. ${ }^{37}$ Count P. A. Kleinmichel, head of the Main Administration of Transport and Buildings, who had always been in favor of the straight route himself, ${ }^{38}$ approved this conclusion, and, on February 4, 1843, forwarded the decision of the Technical Commission

35. Voronin, "K istorii izyskanii i proektirovaniia," pp. 47, 54-55; S. A. Urodkov, Peterburgo-Moskovskaia zheleznaia doroga: Istoriia stroitel'stva (1842-1851 gg.) (Leningrad, 1951), pp. 70-71; see also Sbornik svedenii o zheleznykh dorogakh $v$ Rossii, vol. 1 (St. Petersburg, 1867), pp. 66-67.

36. On August 11,1842, Count P. A. Kleinmichel, who had been a member of both the Construction Committee and the Construction Commission, had become head of the Main Administration of Transport and Buildings, which was now to administer the construction of the railway through a newly created Department of Railways attached to it (Polnoe sobranie zakonov rossiiskoi imperii, 2nd ser., 17, no. 15950 [August 11, 1842], p. 844 [hereafter cited as $P S Z$ ]).

37. Urodkov, Peterburgo-Moskovskaia zheleznaia doroga, p. 71.

38. "Zapiski senatora K. I. Fishera," p. 453. 
to the Construction Committee, which debated the matter in its meeting of February 18. Eight members, that is, the majority of the Committee-including Grand Duke Alexander Nikolaevich-agreed with the views of Mel'nikov and the Technical Commission, stating that Novgorod, after all, would be connected to the railway by both the Volkhov River and the Moscow Chaussée. ${ }^{39}$

Count Kiselev, however, submitted a special memorandum-and this is one instance where the concept of building railways in order to develop the economy of Novgorod can be discerned-in which he argued for building via Novgorod, stating that the absence of a railway would hinder Novgorod's economic development by discouraging private investment in land and construction, perhaps even causing its population to decline, at a time when the government was trying to encourage the growth of cities as a market for agricultural products. He was supported by three other members, including L. A. Perovskii, minister of the interior. ${ }^{40}$

Nicholas, who now had to make the final decision, decided first to discuss the matter personally with Mel'nikov, whose opinion he seemed to respect. Mel'nikov repeated his argument that most traffic would travel between the capitals, and it should not be forced to pay higher rates for the added distance via Novgorod, especially since through traffic would increase many times over as additional railways were built radiating out from Moscow into all parts of Russia. ${ }^{41}$

On February 22, 1843, the tsar made the final decision. He wrote the following order to the Construction Committee: "Build the railway in a straight line, for I cannot find a single valid reason to build it via Novgorod, which will not be deprived of the advantages which it now enjoys." 42 By way of further explanation, he submitted a memorandum to the Committee stating that he did not agree with Kiselev and his supporters, because Novgorod still had water and road communications. Many goods would continue to be shipped by. water through Novgorod since it would still be advantageous to do so. ${ }^{43}$ As for the Moscow Chaussée, its main advantage for Novgorod was, in the tsar's opinion, that coach passengers and carters traveling along the road paused to spend the night in Novgorod. After the railway was built, even if via Novgorod, through passengers and freight would go by railway and would no longer stop in Novgorod, since both capitals could be reached in a matter of hours. The tsar concluded by remarking somewhat sharply that the only advantage would be for those residents of Novgorod who wished to board the train directly instead of boarding it in Chudovo. ${ }^{44}$

39. V. V. Salov, "Nachalo zheleznodorozhnogo dela v Rossii, 1836-1855," Vestnik Evropy, 1899, no. 4, p. 592; Kislinskii, Nasha zheleznodorozhnaia politika, p. 28.

40. Kislinskii, Nasha zheleznodorozhnaia politika, pp. 27-28; Urodkov, PeterburgoMoskovskaia zheleznaia doroga, p. 71. Perovskii was concerned about the supervision and control of the large number of passengers expected to travel on the railway and felt that Novgorod would provide a good headquarters for his police (V. S. Virginskii, Vozniknovenie zheleznykh dorog $v$ Rossii do nachala 40-kh godov XIX veka [Moscow, 1949], p. 231).

41. "Vospominaniia Valeriana Aleksandrovicha Panaeva," Russkaia starina, 107 (1901): 36.

42. Kislinskii, Nasha zheleznodorozhnaia politika, p. 28.

43. The Benckendorff commission had estimated that most of the bulky, low-cost goods shipped by water would not be lost to the more expensive railway (Krasnyi arkhiv, 76 [1936]: 139).

44. Kislinskii, Nasha zheleznodorozhnaia politika, p. 29. 
Thus the tsar's decision was reached after a thorough examination of the problem and accorded with the wishes of the merchants of the two capitals, all of the tsar's most competent engineers led by Mel'nikov, and a majority of high officials, all of whom used mainly economic arguments in presenting their case. The main purpose of the railway was to link St. Petersburg with Moscow and "surplus Russia" south of the Oka River. ${ }^{45}$ The railway would also have military value, but the tsar, when he talked of rapid military transport by railway, was thinking in terms of saving several weeks vis-à-vis transport by Chaussée and not just a few hours through a shorter railway route, as the Ruler Legend would have posterity believe. ${ }^{46}$ This route was favored not for the purpose of a little additional speed but rather for economy in military transport, because most military traffic would be carried the entire length of the railway and building via Novgorod would have increased transport costs by 5 percent.

Compared to the economic interests of Russia as a whole, the interests of areas in "deficit Russia," like Novgorod, were of secondary importance. Novgorod would still have good connections with the railway by Chaussée to Chudovo (46 miles) and by the Volkhov River to a landing called Sosninskaia Pristan' five miles southeast of Chudovo (42 miles). Thus, nearly two-thirds of the journey to St. Petersburg would be by railway. After completion of the railway, considerable efforts were made to assure that Novgorod enjoyed its benefits through the establishment of connecting diligence and steamboat service. In June 1852, the Post Office Department introduced regularly scheduled connecting stagecoach service for passengers and mail between Novgorod and Chudovo. A private entrepreneur started steamboat service for both freight and passengers to Sosninskaia Pristan', where the government built a railway station. ${ }^{47}$ Although traffic along these routes increased gradually, it was not heavy enough to necessitate construction of a branch railway until the beginning of the $1870 \mathrm{~s}$. In May 1871, a narrow-gauge railway, built using St. Petersburg and Viennese capital, was opened between Novgorod and Chudovo. ${ }^{48}$

Despite the reasonableness of Nicholas I's decision, the Ruler Legend nevertheless came into being. It may originally have been an indirect product of the relatively liberal period of the reign of Alexander II from 1855 to 1865 , when Russians and foreigners wanted to believe that Alexander's reign was far more enlightened than that of his father, who had acted invariably as an arbitrary and ignorant soldier. By the same token, there may have been a relationship between the growing disillusionment with Alexander II after 1865 and the partial rehabilitation of Nicholas I. Certainly, many Russians had come to understand that Alexander was perhaps just as much an autocrat at heart as his father was, but that, compared to Nicholas, he was a weak man and increasingly unable to

45. As had been predicted, the greatest amount of freight and passenger traffic did originate in the two capitals and went the entire length of the railway (Vestnik promyshlennosti, 1860 , no. 5 , sec. 3 , pp. $170-75$, and 1860 , no. 6, sec. 3, pp. 191-92).

46. Whereas it would have taken over four weeks to transport a military unit by Chaussee between the capitals, by railroad the trip required only 48-62 hours (see G. N. Karaev, Vozniknovenie sluzhby voennykh soobshchenii na zheleznykh dorogakh Rossii, 18511878 [Moscow, 1949], pp. 39-40; PSZ, 27, no. 26758 [November 10, 1852], pp. 657-58).

47. Kommercheskaia gazeta, June 10, 1852, p. 265, and June 23, 1851, p. 289.

48. V. M. Verkhovskii, Kratkii istoricheskii ocherk nachala i rasprostraneniia zheleznykh dorog v Rossii po 1897 g. vkliuchitel'no (St. Petersburg, 1898), pp. 191-92. 
cope with disunity, disorder, and challenges to his regime. Under such circumstances many Russians would look back nostalgically to the era of Nicholas I, with its aura of authority and stability. The straight route of the railway came to be a symbol of a time when problems were solved in a simple, decisive, and straightforward manner. As one writer later put it in praising Nicholas I's decision: "The whole reign of Nikolai Pavlovich was straightforward [priamolineino]." 49

In any event, the Ruler Legend in its original form is an example of the sort of rumor that can spread in a society in which the governmental decisionmaking process does not function openly and in which an articulate segment of the population is basically ill-disposed toward those who govern them. The legend as it originally came into being is thus not so illustrative of the person and reign of Nicholas I as they actually were, but rather as his detractors, both Russian and foreign, conceived them to have been. ${ }^{50}$

49. P. B., "Graf P. A. Kleinmikhel'," Russkii arkhiv, 32, book 3 (1894) : 590.

50. Cf. W. Bruce Lincoln, "Reform and Reaction in Russia: A. V. Golovnin's Critique of the 1860's," Cahiers du monde russe et soviétique, 16, no. 2 (April-June 1975): 174, n. 35. 